\title{
Analisis Genetik dan Seleksi Segregan Transgresif pada Populasi F2 Sorgum Hasil Persilangan B69 $\times$ Numbu dan B69 $\times$ Kawali
}

\section{Genetic Analisys and Transgressive Segregant Selection of F2 Sorgum Population Derived from B69 $\times$ Numbu and B69 $\times$ Kawali Crosses}

\author{
Marina Yuniawati Maryono ${ }^{1}$, Trikoesoemaningtyas ${ }^{2 *}$, Desta Wirnas², dan Soeranto Human ${ }^{3}$ \\ ${ }^{1}$ Program Studi Pemuliaan dan Bioteknologi Tanaman, Sekolah Pascasarjana, Institut Pertanian Bogor \\ ${ }^{2}$ Departemen Agronomi dan Hortikultura, Fakultas Pertanian, Institut Pertanian Bogor \\ (Bogor Agricultural University), Jl. Meranti, Kampus IPB Darmaga, Bogor 16680, Indonesia \\ ${ }^{3}$ Pusat Aplikasi Isotop dan Radiasi Badan Tenaga Nuklir Nasional (BATAN) \\ Jl. Lebakbulus Raya Pasar Jumat, Jakarta 12440, Indonesia
}

Diterima 29 Januari 2019/Disetujui 6 Mei 2019

\begin{abstract}
The genetic analysis and selection of transgressive segregants on agronomic characters are required in a sorghum breeding program for obtaining high proportion homozygosity rapidly in the early generations. This study aimed to obtain the information on the performance of agronomic characters, estimate genes' action, broad-sense heritability, coefficient of genetic variability, and select transgressive segregant on F2 population of sorghum based on grain yield. The research was conducted from July 2014 until October 2014 in Dramaga, Bogor. About 300 and 150 individuals F2 populations of B69 $\times$ Numbu and B69 $\times$ Kawali, respectively, were used as genetic materials. The results showed that plant height and panicle length of B69 $\times$ Numbu and B69 × Kawali populations were controlled by many genes with additive gene action. The grain yield and grain yield per panicle were controlled by many genes with additive gene action and complementary epistasis, had high heritability, and large coefficients of genetic variability. The transgressive segregant selection had selected 14 individuals of B69 $\times$ Numbu and 134 individuals of B69 $\times$ Kawali populations based on grain yield per panicle.
\end{abstract}

Keywords: gene action, genetic variability, heritability, sorghum rice

\section{ABSTRAK}

Analisis genetik dan seleksi segregan transgresif pada karakter agronomi diperlukan dalam program pemuliaan tanaman sorgum untuk mendapatkan proporsi homozygositas tinggi dengan cepat pada generasi awal. Penelitian ini bertujuan untuk memperoleh informasi tentang keragaan agronomi, aksi gen, keragaman genetik, dan seleksi segregan transgresif berdasarkan karakter agronomi. Penelitian dilaksanakan dari bulan Juli sampai Oktober 2014 di Dramaga, Bogor. Bahan genetik yang digunakan adalah populasi F2 B69 × Numbu, B69 × Kawali dan lima kontrol. Setiap populasi terdiri atas 300 individu F2 dan 150 individu kontrol. Hasil penelitian menunjukkan karakter tinggi tanaman dan panjang malai pada populasi B69 × Numbu dan B69 × Kawali dikendalikan oleh gen-gen aditif. Karakter bobot malai dan bobot biji per malai pada kedua populasi dikendalikan oleh gen-gen aditif dan epistasis komplementer dengan nilai heritabilitas arti luas tergolong tinggi dan koefisien keragaman genetik luas. Karakter bobot malai atau bobot biji per malai dapat digunakan untuk menyeleksi segregan transgresif. Terdapat 14 individu pada persilangan B69 × Numbu dan 134 tanaman pada populasi $B 69 \times$ Kawali yang diduga sebagai segregan transgresif berdasarkan bobot biji per malai.

Kata kunci: aksi gen, heritabilitas, keragaman genetik, beras sorgum

\section{PENDAHULUAN}

Sorgum (Sorghum bicolor (L.) Moench) merupakan salah satu komoditas serealia yang potensial untuk dikembangkan dan dibudidayakan di Indonesia. Sorgum

\footnotetext{
* Penulis untuk korespondensi. e-mail: trikadytia@gmail.com
}

merupakan tanaman penting di dunia setelah beras, gandum, jagung, dan barley (Reddy et al., 2012). Sebagai bahan pangan alternatif, sorgum memiliki kandungan nutrisi yang baik, bahkan kandungan protein, kalsium, dan vitamin B1 yang lebih tinggi dibanding beras dan jagung (DEPKES RI, 1992; Suarni, 2012). Keunggulan lain sorgum terletak pada sifat ketahanan terhadap kekeringan, produksi tinggi, biaya 
produksi relatif murah serta lebih tahan terhadap serangan hama dan penyakit dibanding tanaman pangan lain (Talanca dan Andayani, 2013).

Produksi sorgum masih rendah di Indonesia karena beberapa faktor, seperti luas lahan yang terbatas, penelitian dan pengembangan tanaman sorgum yang belum maksimal, nilai keunggulan komparatif dan kompetitif sorgum yang relatif masih rendah, serta usaha tani sorgum yang belum intensif (Sirappa, 2003). Salah satu cara untuk mendukung pengembangan sorgum di Indonesia adalah dengan melakukan upaya perakitan varietas unggul untuk meningkatkan produktivitas dan kualitas sorgum. Sampai saat ini produksi sorgum masih terbatas.

Varietas unggul sorgum berdaya hasil tinggi dapat diperoleh dengan melakukan seleksi pada populasi bersegregasi. Populasi bersegregasi adalah kumpulan individu-individu yang dihasilkan dari suatu persilangan dan berpotensi menghasilkan keragaman. Segregasi maksimal terjadi pada generasi awal F2 sehingga keragaman genetiknya sangat tinggi dan berpotensi menghasilkan segregan transgresif. Segregan transgresif terjadi disebabkan adanya efek kendali gen over dominan dan aditif. Jika efek aditif yang terjadi, maka akan terfiksasi dan diwariskan pada generasi awal. Segregan transgresif dapat diprediksi pada generasi F1 berdasarkan daya gabung umum dan diamati pada generasi awal persilangan, yaitu pada generasi F2 atau F3 dengan akurasi terbaik pada generasi F3 (Chahota et al., 2007; Jambormias et al., 2014).

Sebagai upaya untuk mengembangkan varietas sorgum, Departemen Agronomi dan Hortikultura IPB telah menghasilkan beberapa persilangan sorgum di antaranya adalah persilangan antara B69 $\times$ Numbu dan B69 $\times$ Kawali. Berdasarkan penelitian Rini et al. (2016) diketahui bahwa galur B69 sebagai tetua betina serta varietas Numbu dan Kawali sebagai tetua jantan memiliki daya gabung umum (DGU) yang baik.

Tetua yang digunakan pada persilangan merupakan tetua yang memiliki keunggulan berbeda. Galur mutan B69 berasal dari varietas Durra hasil irradiasi sinar gamma oleh Pusat Aplikasi Isotop dan Radiasi (PAIR), Badan Tenaga Nuklir Nasional (BATAN) dengan dosis 200 Gy (Sihono, 2009). Varietas Numbu dan Kawali merupakan hasil introduksi dari ICRISAT (Talanca dan Andayani, 2013). Varietas Numbu memiliki potensi hasil lebih baik dibanding varietas Kawali, memiliki tipe malai kompak, biji berukuran besar, mudah dirontokan, biji berwarna krem, daya adaptasi luas, toleran tanah masam, serta tahan terhadap penyakit karat dan bercak (Balitsereal, 2011). Varietas Kawali memiliki batang pendek dan bentuk malainya rapat agak menutup sehingga kurang disenangi burung (Talanca dan Andayani, 2013). Galur B69 memiliki tinggi tanaman pendek yaitu $184.6 \mathrm{~cm}$ (Sihono, 2009) dan potensi hasil 3.7 ton $\mathrm{ha}^{-1}$ (Human et al., 2011), namun peka terhadap tanah masam (Sulistyowati, 2015). Diharapkan pada populasi hasil persilangan B69 dengan Numbu atau Kawali akan diperoleh segregan dengan keragaan tinggi tanaman dan hasil lebih baik dibandingkan tetuanya. Tujuan penelitian ini adalah memperoleh informasi tentang keragaan agronomi, aksi gen, keragaman genetik, heritabilitas dan segregan transgresif berdasarkan karakter hasil pada populasi F2 hasil persilangan sorgum B69 $\times$ Numbu dan B69 $\times$ Kawali.

\section{BAHAN DAN METODE}

Penelitian ini dilakukan di Desa Setu Leutik, Dramaga, Kabupaten Bogor, Jawa Barat pada bulan Juli sampai Oktober 2014. Bahan genetik yang digunakan adalah 2 populasi F2 sorgum yaitu B69 $\times$ Numbu dan B69 $\times$ Kawali. Setiap populasi terdiri atas 300 tanaman generasi F2 dan masing-masing tetua 150 tanaman. Masing-masing populasi F2 dan tetuanya ditanam pada waktu dan hamparan yang sama, tapi plot untuk setiap populasi tetua maupun F2 terpisah. Populasi tetua adalah populasi yang digunakan untuk menduga ragam lingkungan, sedangkan populasi F2 digunakan untuk mendapatkan ragam fenotipe.

Tahap awal penelitian adalah pengolahan tanah yang dilakukan seminggu sebelum penanaman. Benih sorgum ditanam sebanyak tiga sampai lima benih per lubang dengan jarak $70 \mathrm{~cm}$ x $10 \mathrm{~cm}$, lalu diberi Karbofuran $3 \mathrm{G}$ dengan dosis $12 \mathrm{~kg} \mathrm{ha}^{-1}$. Pemupukan dilakukan dengan dosis masing-masing pupuk $150 \mathrm{~kg}$ urea ha-1, $100 \mathrm{~kg}$ SP36 $\mathrm{ha}^{-1}$, dan $100 \mathrm{~kg} \mathrm{KCl} \mathrm{ha-1}$. Pupuk urea diberikan dua kali yaitu $2 / 3$ bagian diberikan pada saat tanam sedangkan $1 / 3$ bagian urea diberikan pada saat tanaman telah berumur 21 hari setelah tanam (HST). Penyulaman dilakukan pada waktu satu minggu setelah tanam (MST). Penjarangan dilakukan pada saat dua MST dengan menyisakan satu tanaman pada satu lubang.

Pengamatan yang dilakukan meliputi seluruh individu tanaman dengan karakter agronomi antara lain : tinggi tanaman, diameter batang, jumlah daun, panjang malai, bobot malai dan bobot biji per malai. Tinggi tanaman diukur dari pangkal batang di permukaan tanah hingga ujung malai. Jumlah daun dihitung mulai ruas kedua. Diameter batang diukur pada ruas kedua. Panjang malai diukur dari pangkal malai sampai ke ujung malai. Bobot malai ditimbang setelah malai dikeringkan selama 3 hari dan bobot biji per malai ditimbang setelah dirontokkan.

Analisis data yang dilakukan adalah pendugaan komponen ragam, heritabilitas, dan koefisien keragaman genetik berdasarkan rumus: $\sigma_{\mathrm{e}}^{2}=\left(\sigma^{2} \mathrm{P}_{1}+\sigma^{2} \mathrm{P}_{2}\right) / 2 ; \quad \sigma^{2}=$ $\sigma^{2} \mathrm{~F}_{3} ; \sigma_{\mathrm{g}}^{2}=\sigma_{\mathrm{p}}^{2}-\sigma_{\mathrm{e}}^{2} ; \mathrm{h}_{\mathrm{bs}}^{2}=\left(\sigma_{\mathrm{g}}^{2} / \sigma_{\mathrm{p}}^{2}\right) \times 100 \% ; \mathrm{KKG}=\frac{\sqrt{\sigma^{2} \mathrm{~g}} \mathrm{p}}{\bar{X}}$,
dimana:

$\sigma^{2} \quad$ : Ragam lingkungan

$\sigma^{2} \mathrm{P}_{1} \quad$ : Ragam pada populasi tetua betina

$\sigma^{2} \mathrm{P}_{2} \quad$ : Ragam pada populasi tetua jantan

$\sigma_{\mathrm{p}}^{2} \quad$ : Ragam fenotipe

$\sigma^{2}{ }^{\mathrm{p}} \quad$ : Ragam genotipe

$\mathrm{h}^{2}{ }^{\mathrm{g}}$ : Heritabilitas arti luas

KKG : Koefisien keragaman genetik

Pendugaan aksi gen dan banyak gen pengendali sifat dilakukan berdasarkan analisis sebaran F2 dengan melihat nilai skewness dan kurtosis (Roy, 2000). Seleksi segregan transgresif dilakukan dengan menggunakan karakter seleksi yang dipilih berdasarkan nilai parameter genetik yang 
diperoleh dalam penelitian ini. Selanjutnya dihitung nilai diferensial seleksi dengan cara mengurangi rata-rata bobot biji per malai segregan terpilih dengan rata-rata bobot biji per malai pada populasi yang diseleksi.

\section{HASIL DAN PEMBAHASAN}

\author{
Keragaan Karakter Agronomi Tetua dan Populasi F2 \\ Sorgum
}

Nilai tengah dan nilai kisaran masing-masing karakter pada kedua tetua dan F2 dapat dilihat pada Tabel 1. Hasil pengamatan menunjukkan bahwa varietas Numbu memiliki tinggi tanaman, panjang malai, bobot malai, dan bobot biji per malai berbeda sangat nyata dengan galur B69. Varietas Kawali dan galur B69 memiliki bobot malai dan bobot biji per malai yang tidak berbeda nyata.

Nilai tengah karakter hasil pada populasi F2 hasil persilangan B69 $\times$ Numbu lebih rendah dibanding nilai tengah kedua tetuanya. Terdapat nilai tengah generasi F2 yang berada di antara tetuanya, yaitu tinggi tanaman dan panjang malai. Kisaran F2 yang besar pada karakter bobot malai 14.0-156.0 g dan bobot biji per malai 7.0-124.1 g menunjukkan bahwa terdapat peluang diperoleh individuindividu segregan transgresif berdaya hasil tinggi.

Hasil persilangan B69 × Kawali menunjukkan bahwa nilai tengah populasi F2 lebih tinggi pada karakter jumlah daun, bobot malai, dan bobot biji per malai dibandingkan kedua tetuanya. Nilai tengah generasi F2 yang berada di antara tetuanya yaitu diameter batang, tinggi tanaman, dan panjang malai. Nilai tengah generasi F2 yang demikian disebabkan galur B69 sebagai tetua betina memiliki DGU terbaik untuk karakter panjang malai dan varietas Kawali sebagai tetua jantan memiliki DGU terbaik untuk karakter tinggi tanaman (Rini et al., 2016). Hasil serupa terjadi pada penelitian Wardani et al. (2015), dimana nilai tengah populasi F3 gandum untuk karakter tinggi tanaman dan panjang malai berada di antara nilai tengah kedua tetuanya.

\section{Pendugaan Aksi Gen yang Mengendalikan Karakter Agronomi Sorgum}

Karakter kuantitatif adalah karakter yang dikendalikan oleh banyak gen dan dipengaruhi oleh lingkungan. Statistik deskriptif yang dapat digunakan untuk menduga jumlah gen dan aksi gen yang mengendalikan suatu karakter kuantitatif dalam populasi bersegregasi adalah kemenjuluran (skewness) dan keruncingan (kurtosis). Nilai skewness dan kurtosis untuk karakter agronomi ditampilkan pada Tabel 2.

Pola sebaran karakter bobot biji per malai pada populasi B69 $\times$ Numbu terdapat pada Gambar 1 dan sebaran populasi B69 $\times$ Kawali terdapat pada Gambar 2. Gambar 1 dan 2 menunjukkan bahwa karakter bobot biji per malai memiliki pola sebaran bersifat kontinyu, yang berarti dikendalikan banyak gen, namun berdasarkan nilai kurtosis karakter ini dikendalikan oleh sedikit gen. Umumnya pendugaan aksi gen melalui skewness dan kurtosis dilakukan pada populasi F2. Jika diperoleh kurva sebaran normal dengan skewness dan kurtosis sama dengan nol, maka keragaman disebabkan oleh aksi gen aditif (Roy, 2000).

Nilai skewness positif $(+)$ menunjukkan bahwa karakter tidak hanya dikendalikan oleh aksi gen aditif, tetapi juga terdapat epistasis komplementer. Sebaliknya, jika nilai skewness negatif (-), maka karakter dikendalikan oleh aksi

Tabel 1. Nilai tengah dan kisaran karakter tetua dan generasi F2 sorgum

\begin{tabular}{|c|c|c|c|c|c|}
\hline \multirow[t]{2}{*}{ Karakter } & \multicolumn{2}{|c|}{$\begin{array}{l}\text { Nilai tengah dan } \\
\text { simpangan baku } \\
\text { tetua }\end{array}$} & \multirow[t]{2}{*}{ p-value } & $\begin{array}{c}\text { Nilai tengah dan } \\
\text { simpangan baku } \\
\text { Populasi F2 }\end{array}$ & $\begin{array}{c}\text { Kisaran Populasi } \\
\text { F2 }\end{array}$ \\
\hline & B69 & Numbu & & \multicolumn{2}{|c|}{ B69 $\times$ Numbu } \\
\hline Diameter batang (mm) & $15.6 \pm 1.7$ & $15.7 \pm 1.5$ & $0.96 \mathrm{tn}$ & $12.7 \pm 2.9$ & $6.2-21.5$ \\
\hline Tinggi tanaman (cm) & $178.8 \pm 13.9$ & $254.5 \pm 6.2$ & $0.00 * *$ & $183.4 \pm 32.7$ & $97.0-270.0$ \\
\hline Jumlah daun (helai) & $9.5 \pm 0.5$ & $9.8 \pm 0.6$ & 0.10 tn & $10.6 \pm 1.4$ & $7.0-14.0$ \\
\hline Panjang malai (cm) & $22.6 \pm 2.6$ & $19.4 \pm 0.9$ & $0.00 * *$ & $19.5 \pm 2.7$ & $12.5-27.0$ \\
\hline Bobot malai (g) & $57.0 \pm 8.9$ & $82.3 \pm 13.1$ & $0.00 * *$ & $47.3 \pm 25.7$ & $14.0-156.0$ \\
\hline \multirow[t]{2}{*}{ Bobot biji per malai (g) } & $46.9 \pm 7.7$ & $72.8 \pm 10.1$ & $0.00 * *$ & $34.1 \pm 20.6$ & $7.0-124.1$ \\
\hline & B69 & Kawali & & B69 $\times$ Kawali & \\
\hline Diameter batang (mm) & $15.6 \pm 1.7$ & $14.8 \pm 2.2$ & $0.05^{*}$ & $15.2 \pm 2.4$ & $8.5-23.7$ \\
\hline Tinggi tanaman $(\mathrm{cm})$ & $178.8 \pm 13.9$ & $196.8 \pm 14.2$ & $0.00 * *$ & $181.8 \pm 29.1$ & $102.0-253.0$ \\
\hline Jumlah daun (helai) & $9.5 \pm 0.5$ & $9.3 \pm 0.7$ & $0.21 \mathrm{tn}$ & $10.5 \pm 1.5$ & $8.0-16.0$ \\
\hline Panjang malai (cm) & $22.6 \pm 2.6$ & $20.9 \pm 2.6$ & $0.03 *$ & $22.2 \pm 2.5$ & $16.5-32.5$ \\
\hline Bobot malai (g) & $57.0 \pm 8.9$ & $60.3 \pm 14.7$ & $0.33 \mathrm{tn}$ & $63.2 \pm 25.6$ & $21.0-161.5$ \\
\hline Bobot biji per malai (g) & $46.9 \pm 7.7$ & $42.2 \pm 10.3$ & $0.07 \mathrm{tn}$ & $48.2 \pm 21.1$ & $15.0-122.7$ \\
\hline
\end{tabular}

Keterangan: a : Angka di depan dan di belakang tanda \pm adalah nilai tengah dan simpangan baku. $*, * *=$ nyata pada $\alpha 5 \%$ dan $1 \%$ 


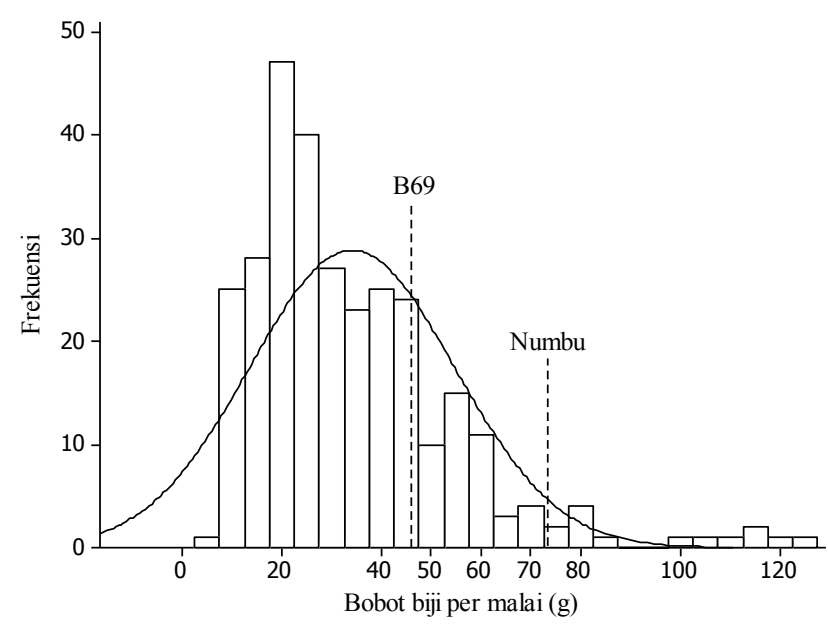

Gambar 1. Pola sebaran bobot biji per malai populasi F2 hasil persilangan B69 x Numbu

gen aditif dan epistasis duplikasi (Roy, 2000). Menurut Roy (2000) dan Jayaramachandran et al. (2010) penyebaran karakter kuantitatif pada tanaman yang menjulur ke kiri atau ke kanan menunjukkan adanya pengaruh lingkungan, interaksi genotipe dan lingkungan, pautan gen dan epistasis.

Berdasarkan hasil uji Z diketahui bahwa karakter tinggi tanaman, jumlah daun, panjang malai pada populasi B69 $\times$ Numbu dan karakter diameter batang dan tinggi tanaman pada populasi B69 $\times$ Kawali tidak berbeda nyata (Tabel 2). Hal ini menunjukkan bahwa karakter tersebut memiliki pola sebaran normal dan dikendalikan oleh aksi gen aditif. Hal ini

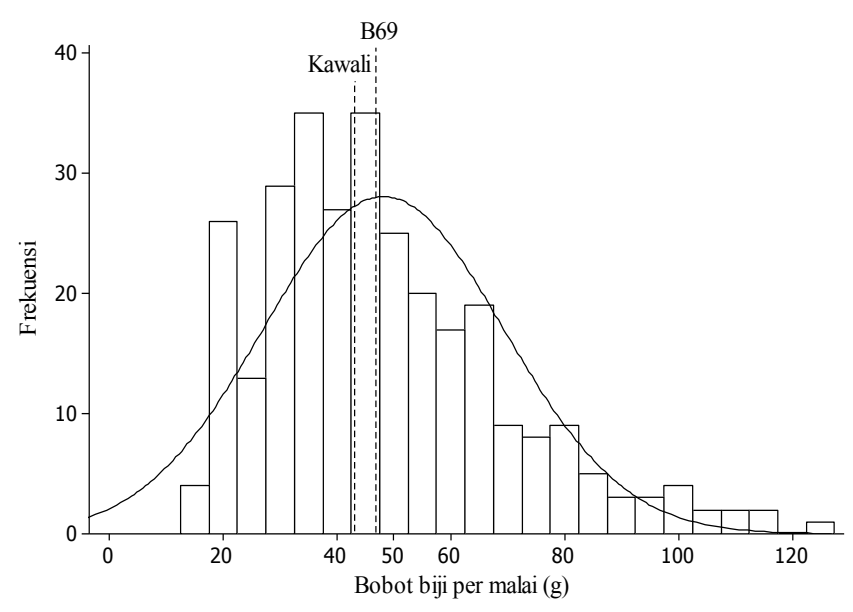

Gambar 2. Pola sebaran bobot biji per malai populasi F2 hasil persilangan B69 x Kawali

sesuai dengan hasil penelitian Insan et al. (2016). Gen-gen aditif menyebabkan kemiripan anak dengan tetuanya dan alel-alel tetua akan diwariskan dari tetua kepada turunannya (Griffiths et al., 2005).

Aksi gen non aditif yang berperan pada populasi yang diamati adalah epistasis aditif dan epistasis komplementer. Epistasis merupakan interaksi antara dua gen atau lebih dari lokus yang berbeda dalam membentuk suatu fenotipe. Epistasis komplementer pada populasi B69 $\times$ Numbu terdapat pada karakter diameter batang, bobot malai dan bobot biji per malai dan pada populasi B69 $\times$ Kawali terdapat pada karakter jumlah daun, bobot malai dan bobot

Tabel 2. Nilai skewness, kurtosis, tipe aksi gen dan jumlah gen pada populasi F2

\begin{tabular}{lcccccccc}
\hline Karakter & $\mathrm{S}$ & $\mathrm{SE}_{\mathrm{S}}$ & $\mathrm{Uji}_{\mathrm{S}}$ & $\begin{array}{c}\text { Tipe } \\
\text { aksi gen }\end{array}$ & $\mathrm{K}$ & $\mathrm{SE}_{\mathrm{K}}$ & $\mathrm{Uji}_{\mathrm{K}}$ & $\begin{array}{c}\text { Jumlah } \\
\text { gen }\end{array}$ \\
\hline B69 x Numbu & & & & & & & & \\
$\quad$ Diameter batang (mm) & 0.55 & 0.14 & $3.93^{* *}$ & Ad+EK & 0.00 & 0.28 & $0.01 \mathrm{tn}$ & Banyak \\
$\quad$ Tinggi tanaman (cm) & -0.19 & 0.14 & $-1.32 \mathrm{tn}$ & Aditif & 0.09 & 0.28 & $0.34 \mathrm{tn}$ & Banyak \\
Jumlah daun (helai) & 0.25 & 0.14 & $1.79 \mathrm{tn}$ & Aditif & -0.21 & 0.28 & $-0.74 \mathrm{tn}$ & Banyak \\
Panjang malai (cm) & 0.05 & 0.14 & $0.39 \mathrm{tn}$ & Aditif & -0.40 & 0.28 & $-1.41 \mathrm{tn}$ & Banyak \\
Bobot malai (g) & 1.51 & 0.14 & $10.69^{* *}$ & Ad+EK & 3.03 & 0.28 & $10.76^{* *}$ & Sedikit \\
Bobot biji per malai (g) & 1.61 & 0.14 & $11.40^{* *}$ & Ad+EK & 3.69 & 0.28 & $13.08^{* *}$ & Sedikit \\
B69 x Kawali & & & & & & & & \\
Diameter batang (mm) & 0.09 & 0.14 & 0.64 tn & Aditif & -0.03 & 0.28 & $-0.13 \mathrm{tn}$ & Banyak \\
Tinggi tanaman (cm) & -0.26 & 0.14 & $-1.83 \mathrm{tn}$ & Aditif & -0.28 & 0.28 & $-0.98 \mathrm{tn}$ & Banyak \\
Jumlah daun (helai) & 0.67 & 0.14 & $4.77^{* *}$ & Ad+EK & 0.21 & 0.28 & $0.74 \mathrm{tn}$ & Banyak \\
Panjang malai (cm) & 0.15 & 0.14 & $1.05 \mathrm{tn}$ & Aditif & 0.34 & 0.28 & $1.22 \mathrm{tn}$ & Banyak \\
Bobot malai (g) & 1.06 & 0.14 & $7.49^{* *}$ & Ad+EK & 1.40 & 0.28 & $4.99^{* *}$ & Sedikit \\
Bobot biji per malai (g) & 0.95 & 0.14 & $6.73^{* *}$ & Ad+EK & 0.78 & 0.28 & $2.77 * *$ & Sedikit \\
\hline
\end{tabular}

Keterangan: $\mathrm{S}=$ skewness; $\mathrm{SE}_{\mathrm{S}}=$ standar eror skewness; $\mathrm{Z}_{\mathrm{S}}=$ statistik uji skewness; $\mathrm{K}=$ kurtosis; $\mathrm{SE}_{\mathrm{K}}=$ standar eror kurtosis; $\mathrm{Z}_{\mathrm{K}}=$ statistik uji kurtosis; ${ }^{*}=$ statistik uji nyata pada taraf $0.01 ; *=$ statistik uji nyata pada taraf $0.05 ; \mathrm{tn}=$ statistik uji tidak nyata; EK $=$ epistasis komplementer 
biji per malai (Tabel 2). Epistasis komplementer adalah interaksi gen dimana fungsi suatu gen akan diperlukan oleh gen lain dalam suatu metabolisme, sedangkan epistasis duplikat adalah interaksi yang hanya berlangsung jika dua gen menghasilkan bahan yang sama untuk membentuk fenotipe yang sama (Roy, 2000; Griffiths et al., 2005). Menurut Sulistyowati (2015) adanya epistasis menunjukkan bahwa untuk mendapatkan segregan harapan dibutuhkan penanaman segregan lebih banyak karena adanya epistasis yang menyebabkan proses fiksasi alel-alel untuk peningkatan homozigositas akan lebih lambat tercapai.

Jumlah gen pengendalikarakterkuantitatifdapat diduga dari nilai kurtosis sebaran. Nilai kurtosis positif $(+)$ artinya karakter dikendalikan oleh sedikit gen. Jika nilai kurtosis negatif (-) menunjukkan bahwa karakter dikendalikan oleh banyak gen. Jumlah gen yang mengendalikan akan mempengaruhi tingkat kesulitan program pemuliaan (Roy, 2000). Berdasarkan nilai kurtosis dan hasil uji $\mathrm{z}$ yang diperoleh dapat diduga bahwa karakter diameter batang, tinggi tanaman, jumlah daun, dan panjang malai pada populasi B69 $\times$ Numbu dan B69 $\times$ Kawali dikendalikan oleh banyak gen. Hasil uji Z karakter bobot malai dan bobot biji per malai pada populasi B69 $\times$ Numbu dan B69 $\times$ Kawali berbeda sangat nyata yang berarti karakter tersebut dikendalikan oleh sedikit gen.

\section{Pendugaan Komponen Ragam dan Heritabilitas}

Pendugaan nilai komponen ragam dilakukan untuk mengetahui proporsi keragaman yang disebabkan oleh faktor genetik dan lingkungan (Roy, 2000). Tabel 3 menunjukkan bahwa seluruh karakter populasi B69 $\times$ Numbu memiliki nilai heritabilitas arti luas yang tinggi. Pada populasi B69 $\times$ Kawali seluruh karakter memiliki nilai heritabilitas arti luas yang tinggi kecuali pada karakter diameter batang dan panjang malai dengan heritabilitas arti luas sedang. Nilai heritabilitas arti luas yang tinggi menunjukkan mudahnya suatu karakter diwariskan pada generasi selanjutnya karena pengaruh faktor genetik lebih besar dari faktor lingkungan (Sami et al., 2013).

Pewarisan sifat suatu karakter sangat ditentukan oleh nilai ragam genetik, heritabilitas dan aksi gen yang mengendalikan karakter tersebut. Suatu karakter mempunyai nilai heritabilitas arti luas rendah dan dikendalikan aksi gen aditif dengan epistasis komplementer maka karakter tersebut dapat diwariskan pada generasi lanjut, sedangkan karakter yang memiliki nilai heritabilitas arti luas tinggi dan dikendalikan aksi gen aditif dengan epistasis komplementer, maka karakter tersebut dapat diwariskan pada generasi berikutnya (Sihaloho et al., 2015). Dengan demikian karakter bobot biji per malai dapat dipilih sebagai karakter seleksi karena memiliki nilai heritabilitas arti luas tinggi dengan aksi gen aditif dan terdapat pengaruh epistasis komplementer. Seleksi pada karakter bobot biji per malai telah dilakukan oleh Sungkono et al. (2009), Mao et al. (2011) dan Sami et al. (2013).

Koefisien keragaman genetik (KKG) merupakan suatu nisbah antara nilai standar deviasi dari ragam genetik dengan nilai rata-rata suatu karakter yang menggambarkan seberapa luas suatu karakter memiliki keragaman genetik. Tabel 3 menunjukkan bahwa keragaman genetik setiap karakter bervariasi dari sempit, sedang, luas. Pada populasi B69 $\times$ Numbu diketahui karakter diameter batang, bobot malai dan bobor biji per malai tergolong dalam keragaman

Tabel 3. Nilai duga komponen ragam, heritabilitas arti luas dan koefisien keragaman genetik pada karakter kuantitatif populasi F2 Sorgum

\begin{tabular}{|c|c|c|c|c|c|}
\hline Karakter & $\sigma_{p}^{2}$ & $\sigma_{\mathrm{e}}^{2}$ & $\sigma_{g}^{2}$ & $\mathrm{~h}_{\mathrm{bs}}^{2}(\%)$ & KKG $(\%)$ \\
\hline \multicolumn{6}{|l|}{ B69 x Numbu } \\
\hline Diameter batang $(\mathrm{mm})$ & 8.67 & 2.17 & 6.51 & $75.03^{\mathrm{T}}$ & 20.08 \\
\hline Tinggi tanaman $(\mathrm{cm})$ & $1,170.30$ & 116.95 & $1,053.35$ & $89.07^{\mathrm{T}}$ & 16.84 \\
\hline Jumlah daun (helai) & 1.96 & 0.32 & 1.64 & $83.61^{\mathrm{T}}$ & 12.12 \\
\hline Panjang malai (cm) & 11.02 & 3.85 & 7.17 & $65.04^{\mathrm{T}}$ & 13.90 \\
\hline Bobot malai (g) & 678.63 & 126.02 & 552.61 & $81.43^{\mathrm{T}}$ & 50.16 \\
\hline Bobot biji per malai (g) & 430.14 & 80.51 & 349.63 & $81.28^{\mathrm{T}}$ & 55.42 \\
\hline \multicolumn{6}{|l|}{ B69 x Kawali } \\
\hline Diameter batang $(\mathrm{mm})$ & 5.97 & 3.52 & 2.46 & $41.15^{\mathrm{s}}$ & 10.29 \\
\hline Tinggi tanaman $(\mathrm{cm})$ & 849.02 & 198.42 & 650.60 & $76.63^{\mathrm{T}}$ & 14.03 \\
\hline Jumlah daun (helai) & 2.30 & 0.41 & 1.89 & $82.25^{\mathrm{T}}$ & 13.08 \\
\hline Panjang malai $(\mathrm{cm})$ & 10.93 & 6.83 & 4.09 & $28.26^{\mathrm{S}}$ & 7.40 \\
\hline Bobot malai (g) & 681.95 & 147.54 & 534.41 & $77.64^{\mathrm{T}}$ & 34.81 \\
\hline Bobot biji per malai (g) & 460.41 & 82.47 & 377.94 & $81.59^{\mathrm{T}}$ & 39.69 \\
\hline
\end{tabular}

Keterangan: $\sigma_{\mathrm{p}}^{2}=$ ragam fenotipe; $\sigma_{\mathrm{e}}^{2}=$ ragam lingkungan; $\sigma_{\mathrm{g}}^{2}=$ ragam genetik; $\mathrm{h}_{\mathrm{bs}}^{2}=$ heritabilitas arti luas; $\mathrm{KKG}=$ koefisien keragaman genetik; $\mathrm{T}=$ tinggi; $\mathrm{S}=\stackrel{\mathrm{e}}{\text { Sedang }}$ 
luas, sedangkan tinggi tanaman, jumlah daun dan panjang malai tergolong dalam keragaman sedang. Pada populasi B69 $\times$ Kawali diketahui karakter bobot malai dan bobor biji per malai tergolong dalam keragaman luas, sedangkan karakter diameter batang, tinggi tanaman dan jumlah daun tergolong keragaman sedang serta panjang malai tergolong dalam keragaman sempit. Bila tingkat keragaman genetik sempit maka keragaman antar individu dalam populasi relatif seragam, sehingga seleksi untuk perbaikan sifat menjadi kurang efektif(Puspitasari et al., 2011). Sebaliknya, semakin luas keragaman genetik maka peluang keberhasilan seleksi dalam meningkatkan frekuensi gen yang diinginkan semakin besar dan seleksi pada karakter kuantitatif dapat dilakukan tanpa mengabaikan nilai tengah populasi yang bersangkutan (Febrianto et al., 2015).

Karakter bobot biji per malai merupakan karakter hasil yang memiliki nilai koefisien keragaman genetik yang tinggi dibandingkan karakter lainnya pada kedua populasi ini. Menurut Haq et al. (2008) apabila suatu karakter memiliki keragaman genetik yang luas maka individu dalam populasi tersebut relatif beragam. Hal ini menunjukkan bahwa pada populasi B69 $\times$ Numbu dan B69 $\times$ Kawali terdapat individu tanaman yang sangat beragam terutama pada karakter bobot biji per malai, artinya terdapat potensi untuk menghasilkan segregan transgresif berdaya hasil tinggi pada kedua populasi.

\section{Seleksi Segregan Transgresif dan Diferensial seleksi}

Salah satu strategi pemuliaan untuk mendapatkan varietas unggul pada tanaman menyerbuk sendiri seperti sorgum adalah seleksi segregan transgresif. Segregan transgresif dapat diprediksi dan diamati pada zuriat suatu persilangan pada generasi awal. Periode seleksi yang panjang dapat diperpendek dengan mendeteksi segregan transgresif di generasi awal. Oleh karena itu, mendeteksi segregan transgresif di generasi awal juga dapat meningkatkan efisiensi seleksi dalam kegiatan pemuliaan tanaman.

Segregasi transgresif membentuk dua gugus segregan dalam spektrum sebaran, yaitu nilai keragaan lebih kecil atau lebih besar dari sebaran tetua (Jambormias dan Riry, 2009). Seleksi tunggal atau single trait selection merupakan seleksi yang dilakukan hanya pada satu karakter saja. Bobot biji per malai merupakan karakter daya hasil yang akan menentukan produktivitas tanaman dan merupakan karakter utama dalam budidaya tanaman karena bernilai ekonomis. Berdasarkan karakter bobot biji per malai pada populasi persilangan B69 $\times$ Numbu terdapat 14 tanaman yang diduga sebagai segregan transgresif, yaitu memiliki bobot biji per malai sebesar $96.0 \mathrm{~g}$ atau lebih. Sementara pada populasi persilangan B69 $\times$ Kawali terdapat 134 individu dengan bobot biji per malai sebesar $66.6 \mathrm{~g}$ atau lebih.

Efektifitas seleksi juga dapat ditentukan dari nilai Diferensial seleksi. Diferensial seleksi merupakan selisih nilai tengah populasi hasil seleksi dengan populasi dasarnya (Roy, 2000). Informasi diferensial seleksi dapat menggambarkan superioritas individu-individu yang terpilih dibandingkan dengan populasi dasarnya. Semakin besar nilai diferensial seleksi maka kemajuan genetik pada populasi terseleksi akan semakin besar. Heritabilitas dan kemajuan genetik yang tinggi mengindikasikan suatu sifat dikendalikan oleh aksi gen aditif dan seleksi akan menjad efektif (Ajay et al., 2014; Kalpande et al., 2014; Kristamtini et al., 2016).

Berdasarkan nilai Diferensial seleksi pada Tabel 4, seleksi pada persilangan B69 $\times$ Numbu menunjukkan peningkatan bobot biji per malai sebesar $62.26 \mathrm{~g}$. Seleksi pada persilangan B69 $\times$ Kawali juga menunjukkan peningkatan bobot biji per malai sebesar $19.32 \mathrm{~g}$. Berdasarkan nilai diferensial tersebut terdapat peluang terjadinya peningkatan bobot biji per malai pada generasi berikutnya (tanaman F3).

Tabel 4. Diferensial seleksi dua populasi persilangan sorgum berdasarkan karakter bobot biji per malai F2 sorgum

\begin{tabular}{lccc}
\hline & \multicolumn{3}{c}{ Bobot biji malai (g) } \\
\hline & $\begin{array}{c}\text { Rata-rata } \\
\text { populasi F2 } \\
\text { awal }\end{array}$ & $\begin{array}{c}\text { Rata-rata } \\
\text { populasi F2 } \\
\text { terseleksi }\end{array}$ & $\begin{array}{c}\text { Diferensial } \\
\text { seleksi }\end{array}$ \\
\hline B.69 x Numbu & 33.74 & 96.00 & 62.26 \\
B.69 x Kawali & 47.84 & 67.16 & 19.32 \\
\hline
\end{tabular}

\section{KESIMPULAN}

Karakter tinggi tanaman dan panjang malai pada populasi B69 $\times$ Numbu dan B69 $\times$ Kawali dikendalikan oleh gen-gen aditif. Karakter bobot malai dan bobot biji per malai pada kedua populasi dikendalikan oleh gen-gen aditif dan epistasis komplementer dengan nilai heritabilitas arti luas tergolong tinggi dan koefisien keragaman genetik luas. Karakter bobot malai atau bobot biji per malai dapat digunakan untuk menyeleksi segregan transgresif. Seleksi berdasarkan bobot biji per malai menghasilkan individu terpilih dengan superioritas sebesar $62.26 \mathrm{~g}$ untuk populasi B69 $\times$ Numbu dan 19.32 g untuk populasi B69 $\times$ Kawali. Terdapat sebanyak 14 individu hasil persilangan B69 $\times$ Numbu dan 134 individu pada persilangan B69 $\times$ Kawali yang diduga sebagai segregan transgresif.

\section{DAFTAR PUSTAKA}

Ajay, B.C., M. Byregowda, B.H. Prashanth, K.G.N. Veera, M. Reena. 2014. Variability and transgressive segregation for yield and yield contributing traits in pigeonpea crosses. Elec. J. Plant Breed. 5:786-791.

[Balitsereal] Balai Penelitian Tanaman Serealia. 2011. Deskripsi varietas sorgum. http://www.balitsereal. litbang.deptan.go.id. [10 Maret 2014]. 
Chahota, R.K., N. Kishore, K.C. Dhiman, T.R. Sharma, S.K. Sharma. 2007. Predicting transgressive segregants in early generation using single seed descent methodderived micro-macrosperma genepool of lentil (Lens culinaris Medikus). Euphytica 156:305-310.

[DEPKES RI] Departemen Kesehatan Republik Indonesia. 1992. Daftar Komposisi Bahan Makanan. Penerbit Bhratara, Jakarta. ID.

Febrianto, E.B., Y. Wahyu, D. Wirnas. 2015. Keragaan dan keragaman genetik karakter agronomi galur mutan putatif gandum generasi M5. J. Agron. Indonesia 43:52-58.

Griffiths, A.J.F., S.R. Wessler, R.C. Lewontin, W.M. Gelbart, D.T. Suzuki, J.H. Miller. 2005. Introduction to Genetic Analysis. New York, USA. W. H. Freeman and Comp.

Haq, U.W., M.F. Malik, M. Rashid, M. Munir, Z. Akram. 2008. Evaluation and estimation of heritability and genetic advancement for yield related attributes in wheat lines. Pak. J. Bot. 40:1699-1702.

Human, S., S. Andreani, Sihono, W.M. Indriatama. 2011. Stability test for sorghum mutant lines derived from induced mutation with gamma-ray irradiation. J. Atom Indonesia 37:102-106.

Insan, R.R., D. Wirnas, Trikoesoemaningtyas. 2016. Estimation of genetic parameters and selection of sorghum (Sorghum bicolor L. Moench) RILS F5 derived from single seed descent. Int. J. Agron. Agric. Res. 8:95-103.

Jambormias, E., J. Riry. 2009. Penyesuaian data dan penggunaan informasi kekerabatan untuk mendeteksi segregan transgresif sifat kuantitatif pada tanaman menyerbuk sendiri (suatu pendekatan dalam seleksi). J. Budidaya Pertanian. 5:11-18.

Jambormias, E., J.R. Patty, J.K.J. Laisina, A. Tutupary, E.L. Madubun, R.E. Ririhena. 2014. Analisis genetik dan segregasi transgresif sifat berganda pada generasi F2 persilangan kacang hijau Mamasa Lere Butnem $\times$ Lasafu Lere Butsiw. J. Budidaya Pertanian. 10:5258.

Jayaramachandran, M., N. Kumaravadivel, S. Eapen, G. Kandasamy. 2010. Gene action for yield attributing characters in segregating generation (M2) of sorghum (Sorghum bicolor L.). Elec. J. Plant Breed 1:802808.
Kalpande, H.V., S.K. Chavan, A.W. More, V.S. Patiland, P.B. Unche. 2014. Character association, genetic variability and component analysis in sweet sorghum (Sorghum bicolor L. Moench). J. Crop Weed. 10:108110.

Kristamtini, Sutarno, E.W. Wiranti, S. Widyayanti. 2016. Kemajuan genetik dan heritabilitas karakter agronomi padi beras hitam pada populasi F2. J. Penelitian Pertanian Tanaman Pangan. 35:119-124.

Mao, D., T. Liu, C. Xu, X. Li, Y.Xing. 2011. Epistasis and complementary gene action adequately account for the genetic bases of transgressive segregation of kilograin weight in rice. Euphytica.180:261-271.

Puspitasari, W., S. Human, D. Wirnas, Trikoesoemaningtyas. 2012. Evaluating genetic variability sorghum mutant lines tolerant to acid soil. J. Atom Indonesia 38:8388 .

Reddy, P.S., J.V. Patil, S.V. Nirmal, S.R. Gadakh. 2012. Improving post-rainy season sorghum productivity in medium soils. Curr. Sci. 102:904-908.

Rini, E.P., Trikoesoemaningtyas, D. Wirnas, D. Sopandie, T.T. Tesso. 2016. Heterosis of sorghum hybrid developed from local and introduced lines. Int. J. Agron. Agric. Res. 8:1-9.

Roy, D. 2000. Plant Breeding Analysis and Exploitation of Variation. Narosa Publishing House, New Delhi, IN.

Sami, R.A., M.Y. Yeye, I.S. Usman, L.B. Hassan, M. Usman. 2013. Studies on genetic variabilty in some sweet sorghum (Sorghum bicolor L. Moench) genotypes. Academic Res. J. Agric. Sci. Res. 1:1-6.

Sihaloho, A.N., Trikoesoemaningtyas, D. Sopandie, D. Wirnas. 2015. Identifikasi aksi gen epistasis pada toleransi kedelai terhadap cekaman aluminium. J. Agron. Indonesia 43:30-35.

Sihono, 2009. Penampilan sifat agronomi galur mutan sorgum [Sorghum bicolor (L.) Moench] di Kabupaten Bogor. J. Ilmiah Aplikasi Isotop Radiasi 5:31-42.

Sirappa, M.P. 2003. Prospects of development of sorghum in Indonesia as an alternative crop for food and industrial. J. Agric. Res. 22:133-140.

Suarni. 2012. Potensi sorgum sebagai bahan pangan funsional. J. Iptek Tanaman Pangan 7:58-66. 
Sulistyowati, Y., Trikoesoemaningtyas, D. Sopandie, S.W. Ardhie, S. Nugroho. 2015. Estimation of genetic parameters and gene actions of sorghum (Sorghum bicolor L. Moench) tolerance to low P condition. Int. J. Agron. Agric. Res. 7:38-46.

Sungkono, Trikoesoemaningtyas, D. Wirnas, D. Sopandie, S. Human, M.A. Yudiarto. 2009. Pendugaan parameter genetik dan seleksi galur mutan sorgum (Sorghum bicolor L. Moench) di tanah masam. J. Agron. Indonesia 37:220-225.
Talanca, A.H., N.N. Andayani. 2013. Perkembangan perakitan varietas sorgum di Indonesia. hal. 94106. Dalam Sumarno, D.S. Damardjati, M. Syam, Hermanto. (Ed.). Sorgum Inovasi Teknologi dan Pengembangan. IARRD. Jakarta.

Wardani, S., D. Wirnas, Y. Wahyu. 2015. Seleksi segregan gandum (Triticum aestivum L.) pada dataran tinggi. J. Agron. Indonesia 43:45-51. 